\title{
Population Density and Intensity of Traffic Connection: Spatial Analysis (Overlay)
}

\author{
Muhammad Ichsan Ali ${ }^{1}$, Muhammad Raiz Abidin ${ }^{2}$ \\ ${ }^{1}$ Department of Civil and Planning, Faculty of Engineering, Universitas Negeri Makassar, Makassar, Indonesia \\ ${ }^{2}$ Department of Geography, Faculty of Mathematics and Natural Sciences, Universitas Negeri Makassar, Makassar, Indonesia
}

\begin{abstract}
Congestion is one of the most significant issues which recently experienced by many cities around the world especially in developing countries such as Indonesia since the world undergoes rapid economic and human development. Rappocini district, one of the districts located in Makassar city Indonesia, is currently experiencing massive construction because of this area based on the urban planning of Makassar city associated as a residential zone which may lead to the massive potential congestion. Therefore, this study tries to analyze how population density intervenes level of service of the road. Traffic survey is a method used to collect primary data in the form of classified traffic data (PCU/hour) then analyzed using the 1997 Indonesian Highway Capacity Manual (IHCM) reference and Highway Capacity Manual (HCM) 2016. Regression analysis (SPSS) and spatial (overlay) which is used later to analyze and visualize the correlation between population density and road service level. The result shows that the population density does not cause the level of congestion. However, congestion is influenced by several factors consisted of the number of populations, population density, highway capacity and the daily average of traffic. Population density value does not influence the level of service of the road because Rappocini district is the main gate to access the Makassar city from the south of Sulawesi; therefore, the congestion mostly caused by the commuter from Gowa and TakalarRegency.
\end{abstract}

Keywords:Congestion, Commuters, Level of Service, Population Density.

\section{Introduction}

Increased congestion on urban roads and off-city roads due to improved vehicle ownership, increased economic activity, limited resources for highway construction, and the low operation of existing traffic facilities, are the main problems in Indonesia as are many other countries in the world. One step that is encouraged is by adding capacity, which will require effective methods that are by the characteristics of traffic in Indonesia for design and planning so that the best value for financing is obtained by considering direct costs and safety and environmental impacts[1].

The development of transportation causes traffic problems in urban areas, including accidents, lack of parking spaces for private vehicles, and traffic congestion[2]. Congestion is a problem in the scope of transportation that is almost faced by all countries in the world. When a state is in the industrial stage where massive infrastructure developments such as the construction of roads and bridges occur, it can have an adverse effect, namely congestion[3]. Congestion increases when the flow is so significant that the vehicles are very close to each other.

Traffic congestion on highways occurs when the traffic flow of vehicles increases with increasing travel demand in each period and the number of road users exceeds the existing capacity [4]. Traffic depends on the capacity of the road, the amount of traffic that wants to move, but if the size of the way cannot accommodate, then the existing traffic will be hampered and will flow according to the maximum road network capacity[5].According to [6], stating that congestion can be caused by factors such as the construction of skyscrapers, expansion of road and bridge networks, traffic rules, driver behavior, and population explosion Increased stinging road users are closely related to population explosion, this is because the population will always do mobility at all times, the mobility referred to here is more emphasized in the movement in an effort to improve welfare[7]. Therefore, an increase in population directly can lead to a rise in the need for the use of transportation equipment such as cars, motorbikes. Moreover, can indirectly cause congestion, especially if the existing road capacity is unable to accommodate the increase in the number of vehicles[8].

The losses incurred because of this congestion problem if quantified in monetary units are enormous, namely losses because the travel time becomes longer and longer, vehicle operating costs become more abundant, and the pollution of vehicles produced increases[9]. In traffic jams the vehicle crawls at a deficient speed, the use of fuel becomes very wasteful, the vehicle's engine wears out faster and the vehicle exhaust produced has a higher concentration content. In conditions of congestion, drivers tend to be impatient which leads to undisciplined actions which ultimately worsen the situation of further congestion[10].

Spatial analysis is a set of methods for finding and describing the level/pattern of a spatial phenomenon so that it can be better understood[11]. By conducting spatial analysis, new information is expected to emerge which can use as a basis for decision making in the area under study [12]. The methods used are very varied, from visual observation to the use of mathematics/applied statistics [3]. As a method, spatial analysis seeks to assist planners in analyzing the condition of the problem based on data from the target area [4]. Moreover, the concepts that underlie a spatial analysis are distance, direction, and relationships. The combination of the three regarding a region will vary to form a significant difference that distinguishes one location from another[13]. Thus, the distance, direction, and relationship between the 


\section{International Journal of Science and Research (IJSR) \\ ISSN: 2319-7064}

Index Copernicus Value (2016): 79.57 | Impact Factor (2017): 7.296

position of an object in an area with objects in another region will have a clear difference [14].

\section{Theoretical Framework}

\subsection{Traffic Characteristics}

Characteristics of traffic are the result of interactions between the driver, vehicle, and road [15]. Therefore, the traffic characteristics of a highway strongly influenced by driver behavior and the road environment. According to [16], the traffic characteristics in the road consist of 3 (three) main parameters, namely:

1) Traffic volume

Based on [17], traffic volume defined as the number of vehicles passing points on the road per unit time, expressed in vehicles/hours, PCU/hour. Traffic volume is calculated based on the equation:

$$
\begin{array}{ll}
\qquad Q=\frac{n}{t} \\
Q \quad=\text { Volume (vehicle/hour) } \\
n \quad=\text { Number of Vehicles (vehicles) } \\
t \quad=\text { Observation Time (hours) }
\end{array}
$$

2) Traffic speed

Speed is the second parameter that describes the characteristics of traffic on the road. Speed defined as the distance traveled by a vehicle on a divided highway with the distance went and usually expressed in units of $\mathrm{km} /$ hour. The speed of traffic flow (S) can be calculated using the formula:

$$
S=\frac{d}{t}
$$

$d=$ Distance $(\mathrm{km})$

$t \quad=$ Travel time (hours)

$s \quad=$ Speed $(\mathrm{km} /$ hours $)$

3) Traffic Density

According to [18], [19], traffic density can be defined as the number of vehicles occupying a certain length of road or lane which generally expressed as the number of vehicles per kilometer per lane (if the road section consists of many lanes). Density is the number of vehicles observed divided by the length of the road. The relationship between volume, speed, and density is as follows:

$$
k=\frac{q}{s}
$$

$k=$ Traffic density (vehicle $/ \mathrm{km}$ )

$q=$ Number of vehicles on the track (vehicle/hour)

$s \quad=$ Traffic speed $(\mathrm{km} /$ hour $)$

\subsection{Highway Capacity}

Road capacity or capacity of a road in a highway system is the maximum number of vehicles that have enough possibilities to pass through the road (in or two directions) in a certain period and with wide road and traffic conditions. While the basic capacity of a highway defined as the capacity of a road that has road characteristics and the nature of the traffic that is considered ideal. Theoretically by assuming a mathematical relationship between density, speed, and current. Capacity stated in Passenger Car Unit
(PCU) [17]. The basic equations for determining capacity are as follows:

$$
C=C_{o} \times F C_{w} \times F C_{S P} \times F C_{S F} \times F C_{C S}
$$

$C \quad$ = Capacity

$C_{o} \quad=$ Basic capacity (vehicle/hour)

$F C_{w}=$ Traffic width adjustment factor

$F C_{s p}=$ Differential adjustment factor

$F C_{s f}=$ Factor adjusting for side barriers

$F C_{c s}=$ City size adjustment factor

\subsection{Degree of Saturation}

The degree of saturation (DS) according to [17], namely as the ratio of road to capacity, which used as the primary factor in determining the level of performance of intersections and road segments. The DS value indicates whether the road segment has a capacity problem or not. The basic equation for determining the degree of saturation (DS) is as follows:

$$
D S=\frac{q}{c}
$$

$D S$ = Degree of Saturation

$q=$ Value of traffic flow (PCU/hour)

$c=$ Road capacity (PCU/hour)

\subsection{Side Barriers}

Side barriers according to [17], [19], namely side activities that can cause conflict and affect the movement of traffic flow and reduce road performance. There are types of occurrences of side barriers are:

- The number of pedestrians walking or crossing along the road segment.

- The number of vehicles stopped and parking.

- The number of motorized vehicles entering and exiting side roads and side roads.

- The slow flow of vehicles, namely the total stream (vehicle/hour) of bicycles, rickshaws, wagon, carts and so on.

The level of side barriers is grouped into five classes from low to very high as a function of the frequency of occurrences of side barriers along the observed road segment. Side barriers determined by the number of weighted events per $200 \mathrm{~m}$ per hour (two sides). Class of side barriers in this study between medium-high.

\subsection{Level of Service}

Level of service (LOS) is a measure of the quality of traffic flow that occurs on the highway where the driver feels the ease and comfort of driving. There are two definitions of the level of service on the road, namely the level of service depends on the flow and the level of service depends on the facility [20]. The level of service of the road that depends on traffic flow is related to the speed of operation which depends on the comparison between the current and the capacity of the way.According to [21], there are six service levels related to current ratios with capacities, namely:

a) Service Level $\mathrm{A}$ is a free flow condition where the value of the current rate with ability ranges from $0.00-0.20$.

b) Service level B is a stable current. This level of service is usually used to design inter-city roads. Value The current ratio with capacity for Service Level B usually ranges from $0.21-0.44$.

\section{Volume 7 Issue 12, December 2018}




\section{International Journal of Science and Research (IJSR) \\ ISSN: 2319-7064}

Index Copernicus Value (2016): 79.57 | Impact Factor (2017): 7.296

c) The level of service $\mathrm{C}$ is the stable current used to design urban roads. The value of the current ratio with capacity for Service Level C ranges from $0.45-0.74$.

d) Service Level D means that the starting current is unstable with the value of the current ratio with capacities ranging from $0.75-0.84$.

e) Level of Service $E$ is that the present is unbalanced where the gift has stagnated where the value of the current ratio with capacity ranges from $0.85-1.00$.

f) Service level F, which is the flow blocked where the vehicle flow has stopped; there are queues and traffic jams. This condition occurs when the value of the current ratio with a capacity exceeds 1.00 .

\section{Research Method}

\subsection{Location}

Rappocini District is one of 14 Subdistricts in Makassar City which borders Panakukang District in the north, Panakukang District and Gowa Regency in the east, Tamalate District in the south and Mamajang District and Makassar District in the west. Rappocini District is a non-coastal area with elevation topography between sea levels. According to the distance, the location of each sub-district to sub-districts ranges from $1 \mathrm{~km}$ to a length of $5-10 \mathrm{~km}$. The map of Rappocini District can be seen in the following Figure 1.

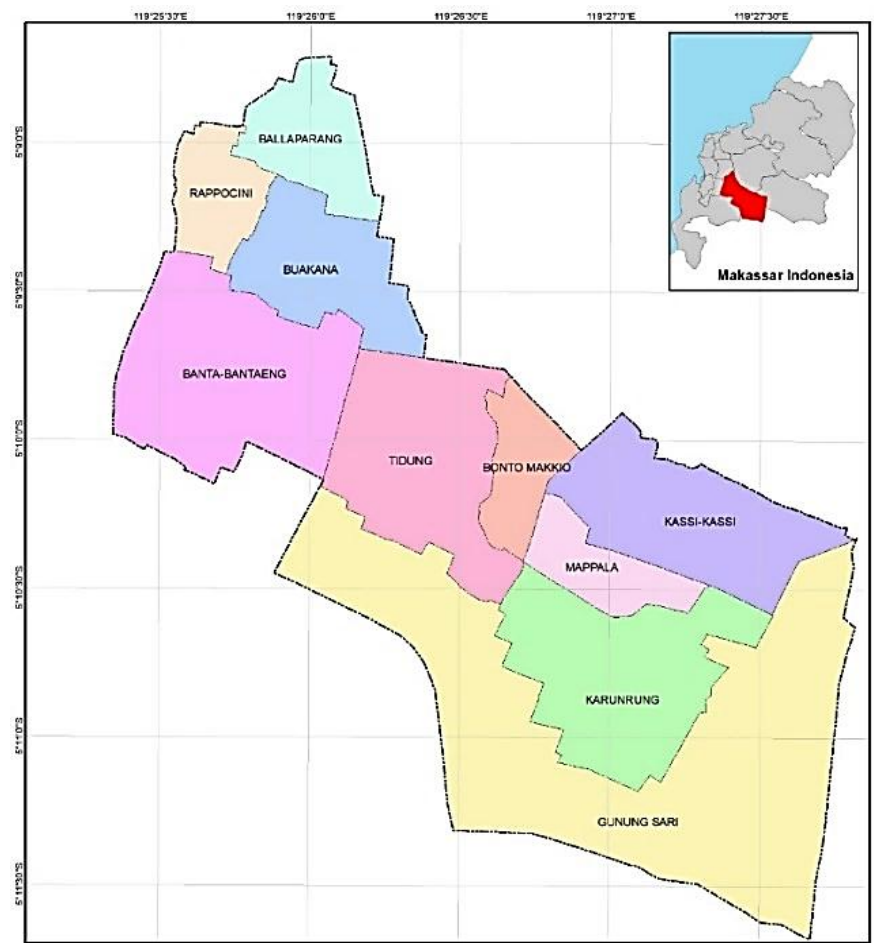

Figure 1: Research Location

The approach used in this study is a mixed quantitativequalitative approach that is in the form of descriptive quantitative-narrative with data collection techniques carried out through primary survey techniques, namely observation or observation of objects and subsequent surveys, through agency surveys and review of documents analyzed quantitatively [22]. The objective of this study is the road network in the District of Rappocini. The variables in this study are 1) Population density; 2) Total population; 3) Road capacity; 4) Daily traffic volume;5) Level of road service (level of service);6) Degree of saturation.

\subsection{Data Collection}

Primary data in the study obtained from traffic surveys conducted on 12 main road segments in Rappocini District, Makassar. Data obtained in the form of traffic volume that classified on the road (PCU/hour), side obstacles on the road, vehicle speed, as well as geometric data of the road.

\subsection{Data Analysis}

The stages of data analysis begin with a review of the road capacity and service level of a road that we have examined through reference to Indonesian Highway Capacity Manual (IHCM) 1997 and Highway Capacity Manual (HCM) 2016. Data analysis then used software, namely SPSS for regression analysis and ArcGIS 10.5 for spatial analysis (overlay). The report later described in the form of diagrams, graphs, maps, tables, then statistical data analysis techniques will be used.

\section{Result and Discussion}

The attribute data used in the analysis and mapping process consists of population data, population density, and area, while the demographic data of Rappocini District can see in the following Table 1.

Table 1: Demographic Attribute Data in Rappocini District

\begin{tabular}{|c|c|c|c|}
\hline Sub-District & Population & Area $(\mathrm{km} 2)$ & Density $($ people/km2) \\
\hline Tidung & 14,935 & 1.176 & 1,270 \\
\hline Mappala & 11,951 & 0.377 & 3,167 \\
\hline Karunrung & 13,059 & 1.266 & 1,031 \\
\hline BontoMakkio & 7,389 & 0.370 & 1,995 \\
\hline Kassi-Kassi & 17,614 & 1.042 & 1,691 \\
\hline Buakana & 11,127 & 0.737 & 1,510 \\
\hline Ballaparang & 12,668 & 0.525 & 2,415 \\
\hline Rappocini & 9,084 & 0.392 & 2,320 \\
\hline Banta-Bantaeng & 20,602 & 1.456 & 1,414 \\
\hline Gunung Sari & 77,388 & 3.519 & 2,199 \\
\hline
\end{tabular}

The table above shows that the most extensive sub-district in Rappocini Sub-District is Gunung Sari Sub-District, while the smallest Sub-District is BontoMakkio Sub-District, then the village with the most population is Gunung Sari SubDistrict, and the least is BontoMakkio Sub-District, then the sub-district that has the highest population density is Mapala Sub-District and the sub-district which has the lowest population density, Karunrung sub-district. The map of the population density level of Rappocini District can see in Figure 2.

\section{Volume 7 Issue 12, December 2018}




\section{International Journal of Science and Research (IJSR)}

ISSN: 2319-7064

Index Copernicus Value (2016): 79.57 | Impact Factor (2017): 7.296

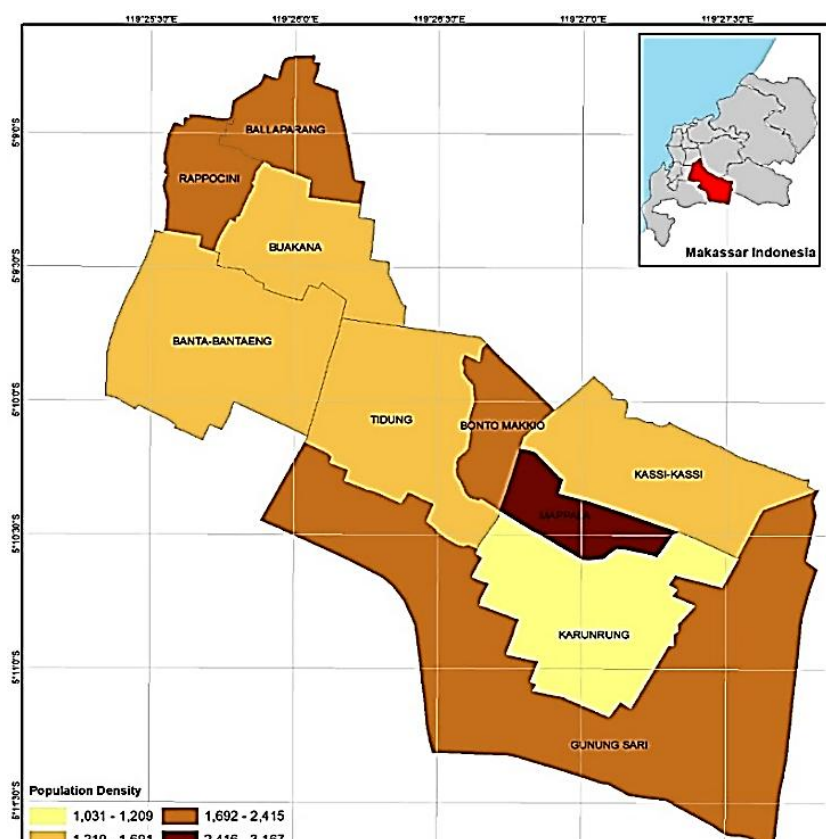

Figure 2: Population Density Conditions in Rappocini

District, Makassar City

\subsection{Road Density}

The attribute data used in the analysis and mapping process consists of average daily traffic volume, road capacity, the degree of road saturation, and level of service. The condition of roads in RappociniDistrict shown in Table 2 based on the Level of Service (LOS) of the streets in Rappocini District was obtained by four categories, namely B, C, D, and E.

Primary and secondary arterial road segments, namely on the road of Sultan Alauddin, A.P. Pettarani, Aroeppala, Hertasning included in the category B service level. The lowest service level category was E only on local roads, namely Emmy Saelan and Yusuf Dg Ngawing roads. Then based on traffic flow, A.P. Pettarani is the road that has the highest traffic flow, while the lowest road is Jipang Raya. The condition of the spread of congestion so that there is no level of road service in the District of Rappocini which falls into category A. One reason is the presence of 2 main road segments or primary arteries that will divide the volume of traffic into local roads around it.

Table 2: Data on the Conditions of the Road Section of the Rappocini District in Makassar

\begin{tabular}{|c|c|c|c|c|c|c|}
\hline Road Name & Road Function & The width of the road (meter) & Traffic Volume $($ PCU $)$ & Road Capacity $($ PCU) & DS & LOS \\
\hline Sultan Alauddin & Primary Artery & 10.00 & 2,659 & 9,340 & 0.28 & $\mathrm{~B}$ \\
\hline A.P. Pettarani & Primary Artery & 12.00 & 3,349 & 11,799 & 0.28 & $\mathrm{~B}$ \\
\hline Syech Yusuf & Secondary Artery & 6.00 & 1,426 & 1,857 & 0.77 & $\mathrm{D}$ \\
\hline LandakBaru & Local & 6.00 & 1,244 & 3,643 & 0.34 & $\mathrm{~B}$ \\
\hline Rappocini Raya & Local & 6.00 & 1,505 & 3,302 & 0.46 & $\mathrm{C}$ \\
\hline Monginsidi & Local & 6.00 & 1,396 & 2,031 & 0.69 & $\mathrm{C}$ \\
\hline Tallasalapang & Local & 6.00 & 1,398 & 1,858 & 0.75 & $\mathrm{D}$ \\
\hline Jipang Raya & Local & 6.00 & 1,108 & 1,405 & 0.79 & $\mathrm{D}$ \\
\hline Aroeppala & Secondary Artery & 10.00 & 2,396 & 6,813 & 0.35 & $\mathrm{~B}$ \\
\hline Hertasning & Secondary Artery & 10.00 & 2,631 & 9,156 & 0.29 & $\mathrm{~B}$ \\
\hline Emmy Saelan & Local & 6.00 & 1,426 & 1,638 & 0.87 & $\mathrm{E}$ \\
\hline Yusuf Dg Ngawing & Local & 6.00 & 1,575 & 1,818 & 0.87 & $\mathrm{E}$ \\
\hline
\end{tabular}

Urban areas have regional characteristics with a population that spread evenly. The aspects of urban areas are due to the needs of the city population with different economic strata and realistic patterns compared to the back area, thus giving rise to the level of the urban regions. In urban areas, it has a different level of the area according to its level. There are levels in urban areas, such as the city center, the space between, and the suburbs. Levels of areas that are dense in urban areas generally have varying degrees of traffic density.

Congestion is a condition in which the flow of traffic passing on road sections that reviewed exceeds the capacity of the road plan which results in the free speed of the road segment approaching or exceeding $0 \mathrm{~km} / \mathrm{hour}$ causing a queue. At the time of congestion, the value of the degree of saturation on the road will be reviewed where congestion will occur if the value of the degree of saturation reaches more than 0.5 [17], [21].

If traffic flow is approaching capacity, congestion starts. Congestion increases when the flow is so significant that the vehicles are very close to each other. Total congestion occurs when the vehicle must stop or move very slowly[15], [16]. Traffic depends on road capacity, the amount of traffic that wants to move, but if the size of the road cannot accommodate, then the existing traffic will be hampered and will flow according to the maximum road network capacity [23]. Traffic jams on highway sections occur when traffic flow of vehicles increases as travel demand increases in each period and the number of roads

\subsection{PopulationDensity and Road Service Level}

The variables that are the emphasis of the review are the level of population density, and the degree of saturation of the road, as for the results of the regression analysis of the value of population density and the degree of saturation of the way can see in Table 3 below.

Table 3: ANOVA Statistical Test

\begin{tabular}{|c|c|c|c|}
\hline & MeanSquare & $F$ & Sig. \\
\hline Regression & 0.190 & 2.427 & 0.150 \\
\hline Residual & 0.078 & & \\
\hline
\end{tabular}

Table 3 shows that the Probability value is $0.150>0.05$, so it can be concluded that there is no relationship between population density and the level of road services in Rappocini District. Research conducted by [24], where the results show that the value of population density affects the frequency of the road simultaneously and significantly. Then

\section{Volume 7 Issue 12, December 2018}




\section{International Journal of Science and Research (IJSR) \\ ISSN: 2319-7064}

Index Copernicus Value (2016): 79.57 | Impact Factor (2017): 7.296

based on the analysis and field survey, it was found that there was no direct effect of population density on the level of road service in Rappocini Subdistrict, because Rappocini District was one of the Districts in Makassar City which directly borders with Gowa Regency, so commuters. The residents of this commuter are residents who live around Gowa Regency or even Takalar Regency who work in Makassar City, while Rappocini District is the gateway to enter Makassar City from the south and there are two primary arterial roads which are the main link or in other words Rappocini District is the main access point to enter Makassar City, so the cause of the increase in road density around Rappocini District is commuters' mobility that comes to Makassar City, while the value of population density does not have an influence on the level of road service in Rappocini District. The results of the overlay analysis between the amount of population density and the value of the level of road services in the District of Rappocini can see in Figure 3 below.

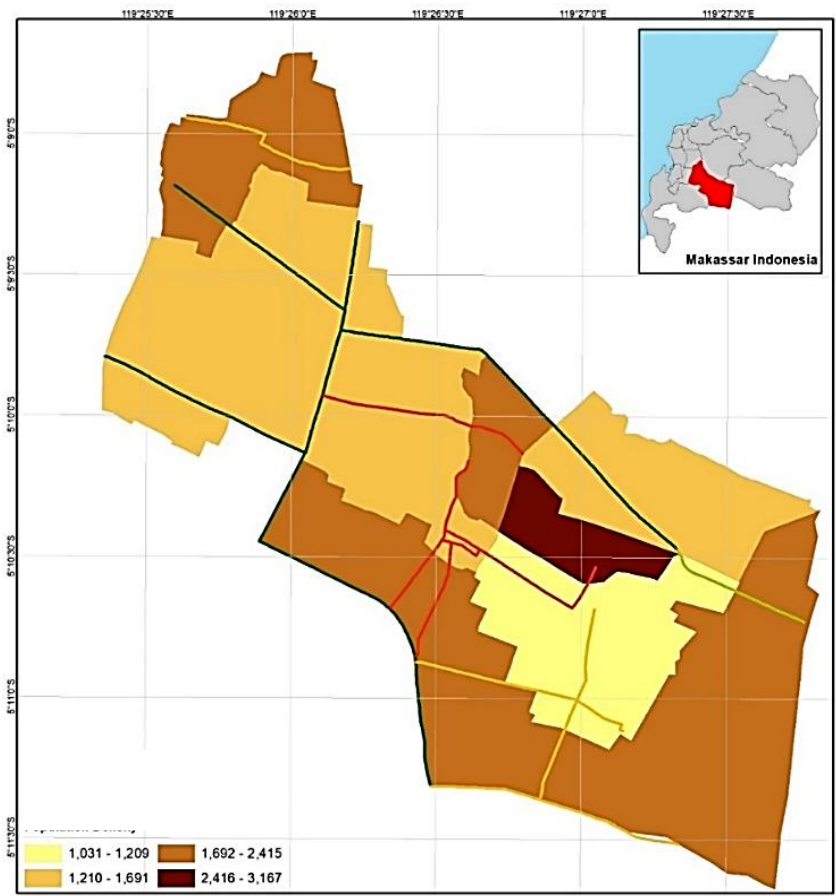

Figure 3: Map of Overlay Population Density Against the Level of Road Services

Figure 3 shows that level of service in Rappocini District dominated by type B service levels such as Sultan Alauddin Road, A.P. Pettarani Road, and Hertasning Road, while the most significant type $C$ service level on Aeropala road then types D service level is at Syeh Yusuf, and Jipang roads and type E service levels spread on Yusuf Dg.Ngawing and Emmy Saelan roads. The results of the overlay analysis show that the areas with the highest population density such as Mapala and Rappocini Sub-districts do not have type E road density levels, while type E road density levels are spread mostly in sub-districts with moderate density such as Gunung Sari and Tidung Sub-districts, even spread in the Sub-districts with the lowest population density, namely Karunrung Sub-districts. So that it can be concluded from the results of the regression and overlay analysis that there is no influence of population density values on the level of service level (level of service) in Rappocini District, Makassar City.

\subsection{Road Density Against Population, Population Density, Road Capacity, and Traffic Flow}

It analyzes also tries to look at the effect of road density on other variables such as population, population density, road capacity, and traffic volume. The outcomes of the analysis show a correlation value of 0.952 with a determination coefficient of $90.7 \%$, meaning that other factors outside the variable influence the independent variable authority's $90.7 \%$ contribution to the dependent variable and the other $9.3 \%$. Compared with the first analysis, it appears that the second analysis has a high correlation value, so it concluded that several factors influence road density. The results of the study can be seen in Table 4 below.

Table 4: Determination Coefficient

\begin{tabular}{|c|c|c|}
\hline$R$ & $R$ Square & Adjusted $R$ Square \\
\hline 0.952 & 0.907 & 0.853 \\
\hline
\end{tabular}

The multiple regression analysis then is proven by the $\mathrm{F}$ test (ANOVA), and the probability value that meets the criteria obtained, then the conclusion is that the level of service influenced by several factors such as population density, population, road capacity, and daily traffic average. The results of the statistical test can see in Table 5 below.

Table 5: ANOVA Statistical Test

\begin{tabular}{|c|c|c|c|}
\hline & Mean Square & F & Sig. \\
\hline Regression & 0.221 & 17.010 & 0.001 \\
\hline Residual & 0.013 & & \\
\hline
\end{tabular}

Based on the results of the analysis show that the probability value is $0.001<0.05$, so it can be concluded that independent variables such as population density, population, road capacity, and average daily traffic significantly affect the level of service in the District Rappocini. The development of commercial buildings that occur in urban areas, especially in Rappocini District, has unwittingly brought a new realism as a gathering place and community activities throughout the day. For example, the construction of shopping centers is an attraction for the community and has become a new choice in meeting the needs of the population today. Everything is in shopping centers starting from primary, secondary and even tertiary needs even though they are available. This phenomenon also indirectly makes shopping centers a favorite place for the community. However, these conditions have a negative impact on traffic, along with the many developments, especially commercial buildings, the movement increases and will have a direct effect on traffic congestion[7].

Very high movement growth rates that are not likely to be inhibited, while transportation facilities and infrastructure are minimal, resulting in impaired accessibility and mobility[25]. However, no matter how much the cost incurred, congestion remains unavoidable; this is due to the development of the provision of transportation facilities that are so low that they cannot follow them. According to [26], traffic congestion that occurs in urban areas is caused by an imbalance between the development of the number of vehicles and the construction of road facilities. Then the lack of awareness of road users in using roads, or road users often disobeying regulations or appropriate traffic signs and regional centers 


\section{International Journal of Science and Research (IJSR) \\ ISSN: 2319-7064}

Index Copernicus Value (2016): 79.57 | Impact Factor (2017): 7.296

that are prone to traffic congestion are generally regions that have the high intensity or concentration of activity centers in a place.

The road network has a vital function, namely as an infrastructure for transferring/transporting people and goods, and is a vein to encourage economic, social, cultural and national stability growth, as well as efforts to distribute and spread development[8]. In a broader dimension, road networks have a significant role in the event of a region, both nationally, provincially, and district/city according to the function of the road network[27].

Traffic congestion itself is a condition where the volume of traffic is greater than the capacity of the road. Traffic jams usually occur on roads that become the central access to community activities in a city[28]. Increasing population increases the level of activity and will directly increase movement in an area[29]. The increasing number of moves in a city will increase the number of uses of transportation facilities both public and private transportation facilities [30]. The expanding number of means of transportation that are not in line with the increase in transportation infrastructure, such as highways, has increased the volume of traffic unable to be accommodated by the capacity of the road[31].

The level of population density greatly influences traffic congestion in urban areas because of increasing population, the use of vehicles is growing because they have the desire to obtain comfort, prestige, and lack of representation Mass transportation might encourage economically capable people to buy and use private vehicles, especially four wheels[32]. Imagine if it turns out that the average four-wheeled vehicle in the city turns out to only carry $1-2$ people every time it travels, it is inevitable that additional vehicle volume and increased road load[33].

\section{Conclusion}

The decreasing level of road services due to the transfer of traffic from now and in the future, the additional capacity needs to be done by possible methods or methods such as pavement widening, reduction of roadside barriers through restrictions on slow and non-motorized vehicles entering the road segment. Population density does not affect the level of service in RappociniDistrict, and it is precisely the level of service (level of service) influenced significantly by several variables such as population, population density, road capacity, and daily traffic volume. Whereas, population density does not affect the level of service (level of service) because Rappocini District is one of the Districts in Makassar City which is the gateway to entering Makassar City from the south so that commuters from Gowaand Takalar Regency influence the road density.

\section{References}

[1] H. Kita, "Level-of-service measure of road traffic based on the driver's perception," Transp. Res. Circ. E-C018 Proc. Fourth Int. Symp. Highw. Capacit., pp. 53-62, 2000.

[2] A. Downs, Stuck in traffic: Coping with peak-hour traffic congestion. Brookings Institution Press, 2005.

[3] B. D. Greenshields, W. Channing, and H. Miller, "A study of traffic capacity," in Highway research board proceedings, 1935, vol. 1935.

[4] M. D. Meyer and E. J. Miller, "Urban transportation planning: a decision-oriented approach," 1984.

[5] B. N. Janson, "Dynamic traffic assignment for urban road networks," Transp. Res. Part B Methodol., vol. 25, no. 2-3, pp. 143-161, 1991.

[6] S. K. Rahane and U. R. Saharkar, "Traffic congestioncauses and solutions: a study of talegaonDabhade city," J. Inf. Knowl. Res. Civ. Eng, vol. 3, no. 1, pp. 160-163, 2014.

[7] J. K. Brueckner, "Urban growth boundaries: An effective second-best remedy for unpriced traffic congestion?," J. Hous. Econ., vol. 16, no. 3-4, pp. 263 273, 2007.

[8] R. Arnott and K. Small, "The economics of traffic congestion," Am. Sci., vol. 82, no. 5, pp. 446-455, 1994.

[9] S. Chandra and U. Kumar, "Effect of lane width on capacity under mixed traffic conditions in India," $J$. Transp. Eng., vol. 129, no. 2, pp. 155-160, 2003.

[10] S. C. Wong and H. Yang, "Reserve capacity of a signal-controlled road network," Transp. Res. Part B Methodol., vol. 31, no. 5, pp. 397-402, 1997.

[11] M. I. Ali and M. R. Abidin, "Spatial Pattern of Crime with Geographic Information System (GIS) in Makassar, Indonesia," Int. J. Sci. Res., vol. 7, no. 4, pp. 451-457, 2018.

[12] J. T. Coppock and D. W. Rhind, "The history of GIS," Geogr. Inf. Syst. Princ. Appl., vol. 1, no. 1, pp. 21-43, 1991.

[13] X. Wang, "Integrating GIS, simulation models, and visualization in traffic impact analysis," Comput. Environ. Urban Syst., vol. 29, no. 4, pp. 471-496, 2005.

[14] Environmental Systems Research Institute, Redlands. ArcView GIS: the geographic information system for everyone. Environmental Systems Research Institute, 1996.

[15] N. J. Garber and L. A. Hoel, Traffic and highway engineering. Cengage Learning, 2014.

[16] R. P. Roess, E. S. Prassas, and W. R. McShane, Traffic engineering. Pearson/Prentice Hall, 2004.

[17] Directorate General Bina Marga, Indonesian Highway Capacity Manual (IHCM). Jakarta: Directorate General of Highway Ministry of Public Works, 1997.

[18] E. K. Morlok and D. J. Chang, "Measuring capacity flexibility of a transportation system," Transp. Res. Part A Policy Pract., vol. 38, no. 6, pp. 405-420, 2004.

[19] E. K. Morlok, Introduction to transportation engineering and planning. McGraw-Hill College, 1978.

[20] R. Dowling et al., Planning and Preliminary Engineering Applications Guide to the Highway Capacity Manual, NCHRP Repo. Washington, D.C: Transportation Research Board, 2016.

[21] Transportation Research Board (National Research Council), Highway Capacity Manual: A Guide for Multimodal Mobility Analysis, 6th ed. Washington, DC: Transportation Research Board, 2016.

[22] P. A. Glasow, "Fundamentals of survey research methodology," Retrieved January, vol. 18, p. 2013, 2005.

\section{Volume 7 Issue 12, December 2018}


[23] C. H. Oglesby and R. G. Hicks, "Highway engineering," 1982.

[24] R. Dunphy and K. Fisher, "Transportation, congestion, and density: new insights," Transp. Res. Rec. J. Transp. Res. Board, no. 1552, pp. 89-96, 1996.

[25] M. Hansen and Y. Huang, "Road supply and traffic in California urban areas," Transp. Res. Part A. Policy Pract., vol. 31, no. 3, pp. 205-218, 1997.

[26] R. Lamm, B. Psarianos, and T. Mailaender, Highway design and traffic safety engineering handbook. 1999.

[27] I. A. N. Spellerberg, "Ecological effects of roads and traffic: a literature review," Glob. Ecol. Biogeogr. Lett., vol. 7, no. 5, pp. 317-333, 1998.

[28] T. Lajunen, D. Parker, and H. Summala, "Does traffic congestion increase driver aggression?," Transp. Res. Part F Traffic Psychol. Behav., vol. 2, no. 4, pp. 225236, 1999.

[29] S. Kingham, I. Longley, J. Salmond, W. Pattinson, and K. Shrestha, "Variations in exposure to traffic pollution while travelling by different modes in a low density, less congested city," Environ. Pollut., vol. 181, pp. 211-218, 2013.

[30] V. Jain, A. Sharma, and L. Subramanian, "Road traffic congestion in the developing world," in Proceedings of the 2nd ACM Symposium on Computing for Development, 2012, p. 11.

[31] A. Anas and R. Xu, "Congestion, land use, and job dispersion: a general equilibrium model," J. Urban Econ., vol. 45, no. 3, pp. 451-473, 1999.

[32] T. Tsekeris and N. Geroliminis, "City size, network structure and traffic congestion," J. Urban Econ., vol. 76, pp. 1-14, 2013.

[33] D. Stokols, R. W. Novaco, J. Stokols, and J. Campbell, "Traffic congestion, Type A behavior, and stress.," $J$. Appl. Psychol., vol. 63, no. 4, p. 467, 1978. 